\title{
Cloning and nucleotide sequence analysis of pepV, a carnosinase gene from Lactobacillus delbrueckii subsp. lactis DSM 7290, and partial characterization of the enzyme
}

\author{
Klaus F. Vongerichten, Jürgen R. Klein, Hugo Matern and Roland Plapp
}

Author for correspondence: Klaus F. Vongerichten. Tel: +49631205 2199. Fax: +496312053799.

Universität Kaiserslautern, Fachbereich Biologie, Abteilung Mikrobiologie, Postfach 3049, 67653 Kaiserslautern, Germany
Cell extracts of Lactobacillus delbrueckif subsp. lactis DSM 7290 were found to exhibit unique peptolytic ability against unusual $\beta$-alanyl-dipeptides. In order to clone the gene encoding this activity, designated pepV, a gene library of strain DSM 7290 genomic DNA, prepared in the low-copy-number plasmid pLG339, was screened for heterologous expression in Escherichia coli.

Recombinant clones harbouring pep $V$ were identified by their ability to allow the utilization of carnosine ( $\beta$-alanyl-histidine) as a source of histidine by the $E$. coli mutant strain UK197 (pepD, hisG). Complementation was observed in a colony harbouring a recombinant plasmid (pKV101), carrying pepV. A 2.4 kb fragment containing pep $V$ was subcloned and its nucleotide sequence revealed an open reading frame (ORF) of 1413 nucleotides, corresponding to a protein with predicted molecular mass of $51998 \mathrm{Da}$. A single transcription initiation site 71 bp upstream of the ATG translational start codon was identified by primer extension. No significant homology was detected between pepV or its deduced amino acid sequence with any entry in the databases. The only similarity was found in a region conserved in the ArgE/DapE/CPG2/YscS family of proteins. This observation, and protease inhibitor studies, indicated that pepV is of the metalloprotease type. A second ORF present in the sequenced fragment showed extensive homology to a variety of amino acid permeases from E. coli and Saccharomyces cerevisiae.

Keywords: $\beta$-alanyl-dipeptides, peptidase $\mathrm{V}$, pep $V$, carnosinase, Lactobacillus delbrueckii subsp. lactis

\section{INTRODUCTION}

Lactobacilli used as starter cultures in dairy fermentations require exogenously supplied amino acids for growth. Due to the rather low content of free essential amino acids in milk they are dependent on their proteolytic abilities to degrade milk casein. Lactobacilli possess a complex proteolytic system composed of proteinases and a variety of peptidases (Abo-Elnaga \& Plapp, 1987; Law \& Kolstadt, 1983; Thomas \& Pritchard, 1987), which act in a cascade to hydrolyse casein to small transportable peptides and amino acids. The quality of dairy products

\footnotetext{
Abbreviations: 3,4-DCl, 3,4-dichloroisocoumarin; E-64, L-trans-epoxysuccinyl-leucylamide-(4-guanidino)-butane; DTP, di-/tripeptidase.

The GenBank/EMBLDDBJ accession number for the nucleotide sequence reported in this paper is $\mathrm{Z31377.}$
}

depends on the property of the proteolytic system since it affects rapidity of growth and concomitant acid production. Moreover, the taste of the fermented food relies on the production of flavourous peptides and amino acids resulting from the degradation of milk casein. In view of the economic importance of lactobacilli, intensive research is currently being carried out to investigate the proteolytic enzymes and the corresponding genes. This could lead to the development of starter strains with improved properties that may be used to increase the efficiency of milk fermentations. Furthermore, genes of individual proteinases and peptidases may serve as markers for the construction of food-grade vectors suitable for genetic engineering.

Only a few Lactobacillus genes coding for proteolytic enzymes have so far been cloned and sequenced, including three genes from Lactobacillus delbrueckii subsp. lactis DSM 
Table 1. Bacterial strains and plasmids

\begin{tabular}{|c|c|c|c|}
\hline Strain or plasmid & $\begin{array}{c}\text { Relevant genotype } \\
\text { or phenotype }\end{array}$ & Replicon, relevant feature & Reference or source \\
\hline \multicolumn{4}{|l|}{ Strains } \\
\hline $\begin{array}{l}\text { Lb. delbrueckii subsp. } \\
\text { lactis DSM } 7290\end{array}$ & $\begin{array}{l}\text { Source of plasmid library, } \\
\text { pep } V^{+}\end{array}$ & & Klein et al. (1993) \\
\hline E. coli $\mathrm{K} 12$, TA3472 & $\Delta($ bisOGDCBHAFIE $)$ & & Ames \& Adeshir (1980) \\
\hline E. coli $\mathrm{K} 12, \mathrm{CM} 17$ & $\mathrm{~F}^{-}$leu-9 $\Delta($ pro-lac $)$ met tby $A$ & & Miller \& Schwartz (1978) \\
\hline E. coli $\mathrm{K} 12$, UK20 & $\mathrm{CM} 17, g l y A$ & & Laboratory collection \\
\hline E. coli K12, UK197 & TA3472, $\Delta(p e p D-p r o B A)$ & & Laboratory collection \\
\hline \multicolumn{4}{|l|}{ Plasmids } \\
\hline pUC18 & & ColE1, high copy number & Yanisch-Peron et al. (1985) \\
\hline pBR322 & & ColE1, medium copy number & Sutcliffe (1979) \\
\hline pJK13 & pepD $D^{+}$ & ColE1, high copy number & Klein et al. (1986) \\
\hline pLG339 & & pSC105, low copy number & Stoker et al. (1982) \\
\hline pWSK129, pWKS130 & & pSC105, from pLG339 & Wang \& Kushner (1991) \\
\hline pKV101 & pep $V^{+}$ & pSC105, from pLG339 & This study \\
\hline $\mathrm{pKV} 102$ & pep $V^{+}$ & pSC105, from pLG339 & This study \\
\hline pKV103 & pep $V^{+}$ & pSC105, from pLG339 & This study \\
\hline pKV104 & pep $V^{+}$ & pSC105, from pLG339 & This study \\
\hline
\end{tabular}

7290 : $p e p X$ encoding the X-prolyl-dipeptidyl-aminopeptidase (Meyer-Barton et al., 1993), pepN encoding a lysylaminopeptidase (Klein et al., 1993) and pepI coding for proline iminopeptidase (Klein et al., 1994). In addition, sequences of pepIP, the proline iminopeptidase gene from Lb. delbrueckii subsp. bulgaricus (Atlan et al., 1994), and of a proteinase gene (Holck \& Naes, 1992) from Lactobacillus paracase $i$ have been published. The peptidase $\mathrm{V}$ from $L i$. delbrueckii subsp. lactis DSM 7290, described in this report, is capable of hydrolysing the peptide bond of the unusual dipeptide $\beta$-alanyl-L-histidine (carnosine) and other $\beta$ alanyl-dipeptides. Carnosinase activities have been previously reported for Salmonella typhimurium (Kirsh et al., 1978), Escherichia coli (Klein et al., 1986) and mammals (Kunze et al., 1986) but, as far as we know, only the gene from E. coli has been cloned and sequenced (Henrich et al., 1990). In this communication we describe the cloning, sequencing and heterologous expression of $p e p V$ from Lb. delbrueckii subsp. lactis DSM 7290 in E. coli. The gene has been designated $p e p V$ in correspondence with a dipeptidase from Lactococcus lactis NCDO 712 (P. Strøman, personal communication), to which it shows significant amino acid homology. Although $p e p V$ complemented a mutation of $p e p D$ in E. coli, the present report indicates that $p e p V$ and $p e p D$ do not belong to the same enzyme family.

\section{METHODS}

Bacterial strains, plasmids and media. The strains and plasmids used are summarized in Table 1. E. coli was grown at $37^{\circ} \mathrm{C}$. either in Luria-Bertani medium (Sambrook et al., 1989) or ir. Davis minimal medium (Davis \& Mingioly, 1950), supplemented with the required amino acids at a concentration of: $50 \mu \mathrm{g} \mathrm{m} l^{-1}, 0.5 \%$ glucose and thiamin $\left(5 \mu \mathrm{g} \mathrm{ml}^{-1}\right.$, final concentration). For selection of $p e p V$ transformants, minimal. medium contained $100 \mu \mathrm{g} \beta$-alanyl-L-histidine $\mathrm{ml}^{-1}$ (Bachem). Kanamycin was added to the culture medium at a concentration of $40 \mu \mathrm{g} \mathrm{ml}^{-1}$ when appropriate. Cultures of $\mathrm{Lb}$. delbrueckii subsp. lactis DSM 7290 were incubated at $42{ }^{\circ} \mathrm{C}$ in MRS medium (De Man et al., 1960).

Transformations. E. coli was transformed by electroporation using a Bio-Rad Gene Pulser as described by Dower et al. (1988). Restriction enzymes and other nucleic-acid-modifying enzymes were obtained from Boehringer Mannheim, United States Biochemical, New England Biolabs, or Pharmacia and were used as recommended by the manufacturers. Isolation of plasmid DNA from E. coli was performed as described by Birnboim \& Doly (1979).

Molecular cloning of pepV from Lb. delbrueckii subsp. lactis. The method used to clone $p e p V$ relied on complementation of UK197, an E. coli pepD mutant (Table 1). In this strain, both relevant markers $p e p D$ and $b i s G$ were deleted. A genomic library of size-fractionated Sau3A fragments of total DNA from $L b$. delbrueckii subsp. lactis DSM 7290 constructed in the low-copynumber vector pLG339 (Stoker et al., 1982), as described by Klein et al. (1994), was used to transform UK197. pep $V$-Positive transformants were identified by their ability to grow on minimal agar plates supplemented with carnosine and kanamycin.

DNA sequence analysis. Nucleotide sequencing of pKV104 was initiated with M13 sequencing primers adjacent to the multiple cloning site, and subsequently oligonucleotide primers (Applied Biosystems, model 392) deduced from the investigated sequences were applied. Double-stranded plasmid DNA, purified on NUCLEOBOND AX100 columns (Macherey-Nagel), was used as a template. The sequence of each strand was determined using the Applied Biosystems model 373A DNA Sequencing System and the required PRISM Ready Reaction DyeDeoxy Terminator Cycle Sequencing Kit, which is based on the dideoxynucleotide chain termination method (Sanger et al., 1977). All chemicals were obtained from Applied Biosystems 
and used as recommended. For computer-assisted DNA and amino acid sequence analyses the Microgenie (Beckman), PC/Gene (IntelliGenetics) and HUSAR (GENIUSnet) software were used.

Isolation of RNA. Total RNA isolation from $L b$. delbrueckii subsp. lactis DSM 7290 was based on the method of Ikemura \& Dahlberg (1973) and was modified as follows. An inoculum of $5 \mathrm{ml}$ overnight ( $16 \mathrm{~h}$ ) culture of Lb. delbrueckii subsp. lactis DSM 7290 was mixed with $5 \mathrm{ml}$ prewarmed MRS medium and incubated for $2 \mathrm{~h}$ at $37^{\circ} \mathrm{C}$. Cells were pelleted by centrifugation, washed once with water, resuspended in $1.14 \mathrm{ml} 6.5 \%(\mathrm{w} / \mathrm{v})$ sucrose in $50 \mathrm{mM}$ Tris $/ \mathrm{HCl}(\mathrm{pH} 8), 1 \mathrm{mM}$ EDTA plus $6.75 \mathrm{mg}$ lysozyme and $50 \mathrm{U}$ mutanolysin (Sigma). After incubation for $1 \mathrm{~h}$ at $37^{\circ} \mathrm{C}, 0.15 \mathrm{ml} 0.25 \mathrm{M}$ EDTA in $50 \mathrm{mM}$ Tris $/ \mathrm{HCl}(\mathrm{pH} 8)$ and $84 \mu \mathrm{l} 20 \%$ SDS were added. The lysed cells were subjected to proteinase $\mathrm{K}$ digestion at a concentration of $50 \mu \mathrm{g} \mathrm{ml} l^{-1}$ for $30 \mathrm{~min}$ at $55^{\circ} \mathrm{C}$. The solution was extracted twice with Tris-buffered phenol ( $\mathrm{pH} 7$ ), once with phenol/ chloroform and twice with chloroform/isoamyl alcohol $(24: 1$, $\mathrm{v} / \mathrm{v}$ ). The supernatant was added to 1 vol. $4 \mathrm{M} \mathrm{LiCl}$ and RNA was allowed to precipitate overnight at $4{ }^{\circ} \mathrm{C}$. After centrifugation $\left(14000 \mathrm{~g}, 20 \mathrm{~min}, 4^{\circ} \mathrm{C}\right)$, the RNA pellet was dissolved in $1 \mathrm{ml} \mathrm{H}_{2} \mathrm{O}$, followed by a second $\mathrm{LiCl}$ precipitation for $4 \mathrm{~h}$ at $4{ }^{\circ} \mathrm{C}$. The pellet was washed in $80 \%(\mathrm{v} / \mathrm{v})$ ethanol, and dissolved in $20 \mu \mathrm{H}_{2} \mathrm{O}$. After a final ethanol precipitation the RNA was stored as an ethanolic suspension at $-70^{\circ} \mathrm{C}$. The RNA concentration was determined by measuring the $A_{260}$ after centrifugation of an aliquot of this suspension and dissolution of the sediment in distilled water $\left(25 A_{\mathbf{2 6 0}}\right.$ units $=1 \mathrm{mg}$ RNA $\left.\mathrm{ml}^{-1}\right)$. RNA preparations were analysed on $1 \%(\mathrm{w} / \mathrm{v})$ agarose gels before use.

Primer extension analysis. To determine the $5^{\prime}$ end of $p e p V$ mRNA, primer extension analysis was performed as described by Henrich et al. (1993), using a synthetic oligonucleotide (27mer, see Fig. 4), which was hybridized to RNA from $L b$. delbrueckii subsp. lactis DSM 7290. The size of the ${ }^{35}$ S-labelled cDNA was determined by a parallel DNA sequencing reaction of a pep $V$ coding plasmid, initiated by the same primer.

Preparation of cell-free extracts. Cell pellets of E. coli from $100 \mathrm{ml}$ of an overnight culture were washed with $20 \mathrm{ml} 50 \mathrm{mM}$ Tris/ $\mathrm{HCl}(\mathrm{pH} 8)$, pelleted by centrifugation at $7000 \mathrm{~g}$ for $10 \mathrm{~min}$ and resuspended in $1 \mathrm{ml}$ of the same buffer. The bacteria were disrupted by ultrasonication on ice (Bandelin sonifier, Sonopuls HD60) and cell debris was removed by centrifugation at $51000 \mathrm{~g}$ and $4{ }^{\circ} \mathrm{C}$ for $60 \mathrm{~min}$. Cell extracts from Lactobacillus were prepared from $50 \mathrm{ml}$ cultures as described by Klein et al. (1993). The supernatant of both preparations contained approximately $50 \mathrm{mg}$ protein $\mathrm{ml}^{-1}$ as determined by the Lowry method. The content of PepV protein in cell extracts was determined videodensitometrically (Cybertech CS1, Image Documentation System) with Coomassie-stained SDS gels, calibrated with serum albumin standards.

Sodium dodecyl sulphate-polyacrylamide gel electrophoresis (SDSPAGE). Crude extracts were analysed by SDS-PAGE $(12.5 \%, \mathrm{w} / \mathrm{v}$, acrylamide) using the discontinuous buffer system of Laemmli (1970). Gels were stained with Coomassie blue according to Weber \& Osborn (1969).

Assay of peptidase $\mathbf{V}$ activity and effects of various chemical reagents. Peptidase $\mathrm{V}$ was assayed in $0.66 \mathrm{ml}$ reaction volumes by incubating $350 \mu \mathrm{l}$ of crude extracts ( $E$. coli or Lb. delbrueck.ii subsp. lactis DSM 7290 ) at $37^{\circ} \mathrm{C}$ in the presence of $0.1 \mathrm{M}$ Tris $/ \mathrm{HCl}(\mathrm{pH} 9), 0.1 \mathrm{M} \mathrm{CoCl}_{2}$, and $7.27 \mathrm{mg} \beta$-alanyl-L-alanine $\mathrm{ml}^{-1}$ as a specific substrate (Kirsh et al., 1978). After 0, 10, 25 and $40 \mathrm{~min}, 0 \cdot 2 \mathrm{ml}$ samples were removed, heated at $90^{\circ} \mathrm{C}$ for $5 \mathrm{~min}$, and centrifuged for $15 \mathrm{~min}$ at $12000 \mathrm{~g}$ and $4^{\circ} \mathrm{C}$. L-Alanine, the product of the reaction, was determined in $180 \mu$ laliquots of the supernatants by an L-alanine dehydrogenase-NAD coupled reaction, exactly as described by Williamson (1985). One unit of peptidase $\mathrm{V}$ activity was defined as the amount of enzyme that liberates $1 \mathrm{nmol} \mathrm{L}$-alanine $\mathrm{min}^{-1}$ under the conditions described.

To study the mechanism of enzyme action, the inhibitors 3,4dichloroisocoumarin (3,4-DCI) at a concentration of $0.1 \mathrm{mM}$, pepstatin $\mathrm{A}$ at $1 \mu \mathrm{g} \mathrm{ml}^{-1}$, L-trans-epoxysuccinyl-L-leucylamido(4-guanidino)-butane (E-64) at $10 \mu \mathrm{M}$, and 1,10-phenanthroline or EDTA at $1 \mathrm{mM}$ were added to the extracts and incubated for $30 \mathrm{~min}$ at $37^{\circ} \mathrm{C}$. The substrate $\beta$-alanyl-L-alanine, was added and activity was measured spectrophotometrically as described above.

Non-denaturating PAGE. Crude cell extracts were subjected to disc gel electrophoresis on polyacrylamide gels $(7 \%, \mathrm{pH} 8)$ according to Davis (1964). After electrophoresis, peptidase activity was detected by incubation of the gels with the reaction mixture in the dark at $37^{\circ} \mathrm{C}$ (Sugiura et al., 1977). The reaction mixture was prepared immediately before use, as follows: $1.3 \mathrm{ml}$ of a $2 \%(\mathrm{w} / \mathrm{v})$ agar solution $\left(45^{\circ} \mathrm{C}\right)$ in $0.1 \mathrm{mM} \mathrm{CoCl}_{2}, 0.1 \mathrm{mM}$ $\mathrm{MnCl}_{2}$, supplemented with $2.5 \mathrm{mg}$ peptide as a substrate, was added to $1.3 \mathrm{ml}$ of a solution containing $5 \mathrm{mg} 2$-( $p$-iodophenyl)3-p-nitrophenyl-5-phenyltetrazolium hydrochloride (INT), $1 \mathrm{mg}$ of phenazine methosulfate (PMS) in $10 \mathrm{ml} 50 \mathrm{mM}$ Tris $/ \mathrm{HCl}(\mathrm{pH} 8)$ and $12 \mu \mathrm{L}$-amino acid oxidase $\left(1 \mathrm{mg} \mathrm{ml}^{-1}\right)$ from Crotalus adamanteus (Boehringer Mannheim). L-Amino acid oxidase efficiently catalyses the deamination of phenylalanine, tyrosine, tryptophan, leucine, isoleucine and methionine, while histidine, arginine and valine are rather poor substrates. All other amino acids are not detectable by this reaction. When using peptides containing $\mathrm{L}$-alanine as substrate, $\mathrm{L}$-amino acid oxidase was replaced by $10 \mu \mathrm{l}$-alanine dehydrogenase $\left(5 \mathrm{mg} \mathrm{ml}^{-1}\right)$ and $100 \mu \mathrm{l} \mathrm{NAD} \mathrm{solution}\left(6 \mathrm{mg} \mathrm{ml}^{-1}\right)$.

\section{RESULTS AND DISCUSSION}

\section{Cloning of pepV from $L b$. delbrueckii subsp. lactis DSM 7290}

Since cloning and transformation procedures are still only moderately successful in lactobacilli we decided to screen the plasmid library of $L b$. delbrueckii subsp. lactis DSM 7290 prepared in the low-copy-number vector pLG339 for heterologous expression in E. coli. Recombinant plasmids carrying $p e p V$ were identified in E. coli UK197 transformants, which were capable of utilizing $\beta$-alanyl-Lhistidine as a source of histidine. The only positive clone which exhibited $p e p V$ activity harboured a recombinant derivative of pLG339, carrying a chromosomal Sau3A fragment $4 \mathrm{~kb}$ in size. This plasmid, designated pKV101, was the subject of further analyses.

\section{Subcloning of pepV and expression in E. coli}

In order to shorten the $p e p V$-containing insert, a $1.6 \mathrm{~kb}$ Sall fragment was deleted from pKV101 (Fig. 1), thus generating $\mathrm{pKV} 102$. This deletion reduced the insert size to $2.4 \mathrm{~kb}$ without affecting the expression of $p e p V$ (Fig. 2). Subcloning of the $2 \cdot 4 \mathrm{~kb} \mathrm{BamHI}-S a l l$ fragment into the vectors pWSK129 and pWKS130 (Wang \& Kushner, 1991) resulted in plasmids pKV103 and pKV104, which carry the inserted DNA in opposite orientations with 


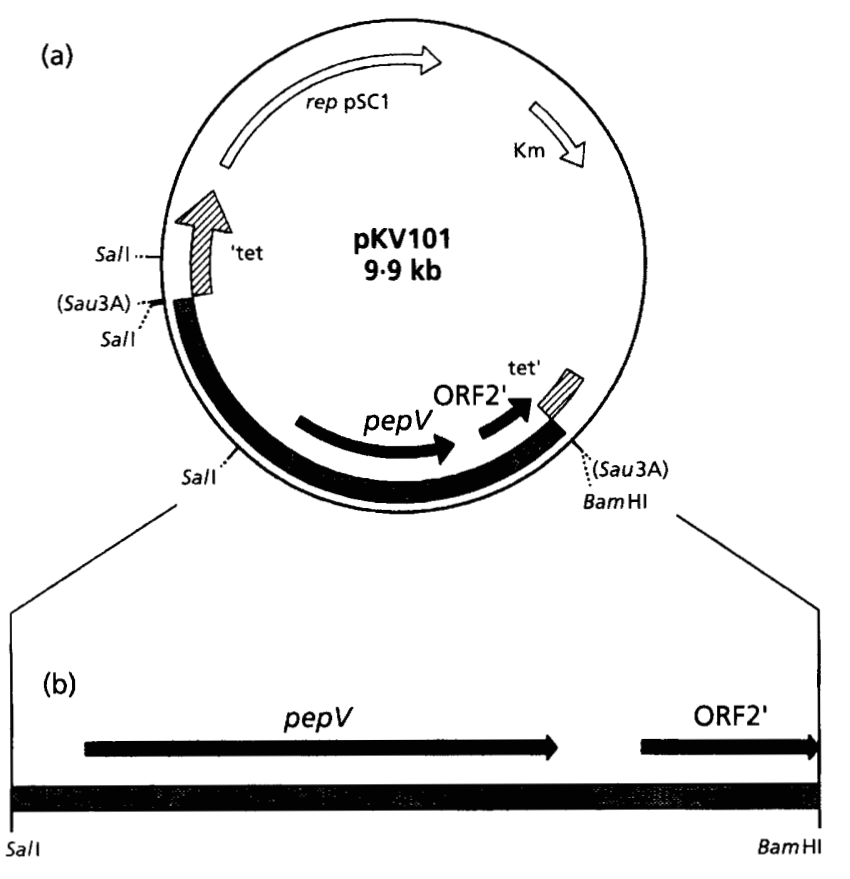

Fig. 1. Genetic map of plasmid pKV101. (a) The chromosomal DNA insert of $4 \mathrm{~kb}$ is indicated as a shaded segment with pepV and ORF2' located along the solid arrows. (b) The $2.4 \mathrm{~kb}$ BamHI-Sall fragment subcloned into pLG339, pWSK129 and pWKS130 is shown as a shaded bar.

respect to the vectorial lac promoters. Peptidase $\mathrm{V}$ was expressed from pKV103 as well as from pKV104 and complemented E. coli UK197 in its peptidase D mutation without induction of the lac promoter, indicating that the original Lactobacillus pep $V$ promoter is likely to be present on the cloned fragment and functional in E. coli. Attempts to clone the $2 \cdot 4 \mathrm{~kb} \mathrm{BamHI}-S a / \mathrm{I}$ section into the highcopy-number vector pUC18 (Raleigh et al., 1988), with pep $V$ in opposition to the lac promoter, as well as into the medium-copy-number vector pBR322 (Sutcliffe, 1979), were not successful.

Cell extracts of E. coli UK197 complemented by the four different pep $V$-containing plasmids (pKV101, pKV102, pKV103 and pKV104) were subjected to SDS-PAGE. As shown in Fig. 2, one additional protein band of $52 \mathrm{kDa}$ appeared specifically in extracts of all the complemented clones, but not in transformants harbouring vector pLG339. These results indicate that the $52 \mathrm{kDa}$ band is likely to represent peptidase V. Expression of pep $V$ in $E$. coli is high since about $25 \%$ of the cytoplasmic proteins are constituted by PepV protein (Fig. 2). The high level of expression under the control of the original promoter might result in lethal over-expression if $p e p V$ is cloned in high-copy-number vectors. This might explain the failure of subcloning pepV in plasmids like pUC18 or pBR322. Comparable observations were made for peptidases $\mathrm{X}$ and N (Meyer-Barton et al., 1993; Klein et al., 1993).

\section{Substrate specificity of peptidase V}

To compare the substrate specificity of the Lactobacillus peptidase $V$ with peptidase D of E. coli, crude extracts of

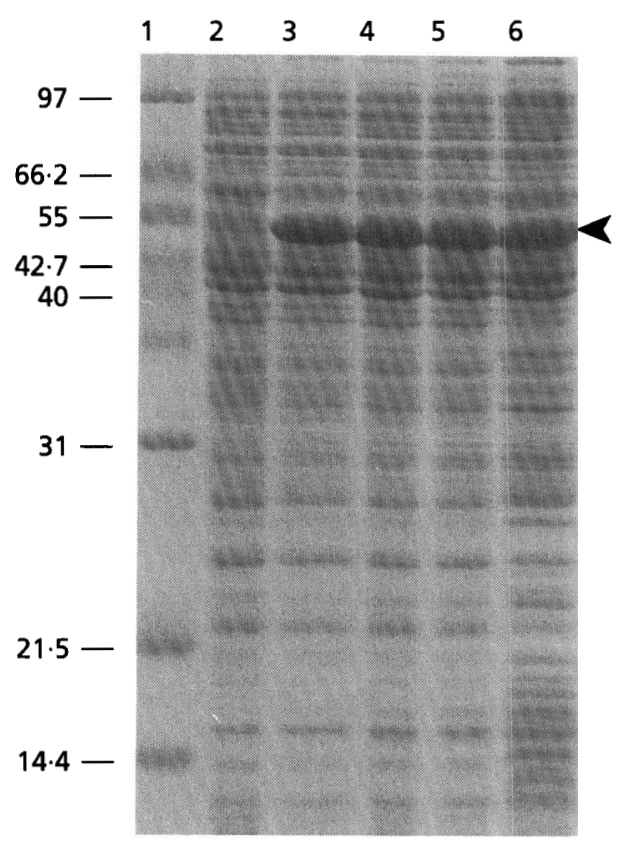

Fig. 2. Expression of pepV in E. coli strain UK197. Crude cell extracts were separated by SDS-PAGE as indicated in Methods. Lanes: 1, molecular mass marker proteins; 2, UK197(pLG339); 3, UK197(pKV101); 4, UK197(pKV102); 5, UK197(pKV103); 6, UK197(pKV104). The position of PepV is marked by an arrowhead.

E. coli strain UK20 [pepD], UK20(pKV102) $\left[p e p V^{+}\right]$or $\mathrm{UK} 20(\mathrm{pJK} 13)\left[p e p D^{+}\right]$, were subjected to native disc gel electrophoresis. The subsequent histochemical staining with a variety of different substrates permitted the detection of the two cloned peptidases in the presence of the host background. Since different peptidases could be easily distinguished by their characteristic $\mathrm{R}_{F}$ values, this method allowed the determination and comparison of substrate specificities without the necessity for protein purification. As visible in Fig. 3, lane 2, a band of $R_{F} 0.9$, indicating peptidase $\mathrm{V}$ activity, could be observed for cellfree extracts of UK20(pKV102) incubated with trimethionine. This band could not be detected for cell-free extracts of UK20 incubated with the same substrate (Fig. 3, lane 1). Peptidase D activity of UK20(pJK13) incubated with $\beta$-alanyl-L-tyrosine as the specific substrate is indicated by a band of $\mathrm{R}_{F} 0.6$ (Fig. 3, lane 3). In Table 2 the substrate specificities of the two peptidases are compared. Both enzymes cleave a variety of dipeptides, especially those with the unusual $\beta$-alanyl residue. While peptidase $V$ was capable of hydrolysing some tripeptides, peptidase $\mathrm{D}$ acts solely as a dipeptidase. The activity of another di-/ tripeptidase (DTP) from Lactobacillus belveticus CNRZ 32 was described by Nowakowski et al. (1993). Since DTP was not further characterized or sequenced, we were only able to compare the two enzymes at the level of substrate specificities. DTP and PepV have some overlapping substrate specificities but we also found substrates which were hydrolysed specifically by only one of the two peptidases. Accordingly, PepV cleaves L-phenylalanyl-Lleucine, but was not active on trileucine, which is a 


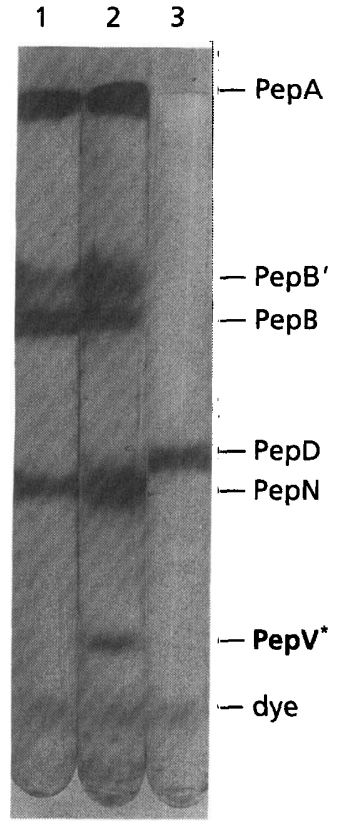

Fig. 3. Activity staining of crude cell extracts separated by native disc electrophoresis after incubation with two different peptides. Lanes: 1, UK20 with trimethionine; 2 , UK20(pKV102) with trimethionine; 3, UK20(pJK13) with $\beta$-Ala-L-Tyr. The peptidase $\mathrm{V}$ activity from $\mathrm{Lb}$. delbrueckii subsp. lactis (marked by an asterisk) is visible in lane 2 beside the $E$. coli peptidases $A$, $B, B^{\prime}$ and N. Activity bands with $R_{F}$ values characteristic of PepD and PepV were observed exclusively in extracts of $E$. coli harbouring the respective plasmids. The results obtained with a wide variety of peptides are summarized in Table 2 .

specific substrate of DTP. On the other hand the PepV substrate L-phenylalaninyl-L-leucine was reported not to be hydrolysed by DTP. This comparison shows that PepV and DTP are different peptidases. However, since both enzymes were isolated from closely related Lactobacillus strains, significant homologies might be expected at the level of nucleotide or amino acid sequences.

In order to determine the mechanism of enzyme action we incubated cell extracts from UK20(pKV102) with different types of protease inhibitors (3,4-DCI for serine proteases, pepstatin A for proteases with aspartate-active sites, E-64 for cysteine proteases and 1,10-phenanthroline or EDTA for metalloproteases). The results indicated that the enzyme is a metalloprotease since full inhibition with 1,10-phenanthroline or EDTA could be detected, whereas the other inhibitors used had no significant effect on enzyme activity. Further characterization of the enzyme will be performed after purification.

\section{DNA sequence analysis}

The nucleotide sequence of the Bam HI-SalI fragment in pKV104 was determined for both DNA strands (Fig. 4). Analysis of the sequence, consisting of $2403 \mathrm{bp}$, revealed the presence of two ORFs separated by $248 \mathrm{bp}$. ORF1 (1413 bp, $54 \cdot 1 \mathrm{~mol} \% \mathrm{G}+\mathrm{C}$ ), starting with an ATG codon at position 221 and extending to the TAA stop codon at
Table 2. Comparison of substrate specificities of Lactobacillus peptidase $V$ and $E$. coli peptidase $D$

Extracts of UK20, UK20(pJK13) and UK20(pKV102) were analysed by activity staining after native PAGE. Extracts of UK20 served as a negative control containing only endogenous E. coli peptidases. The amino acids underlined are those with the potential to react either with the amino acid oxidase or, in the case of alanine, with L-alanine dehydrogenase after release by peptidases. This specificity for distinct amino acids allowed the prediction that Pep V cleaves tripeptides from the $\mathrm{N}$-terminus but not from the carboxy-terminus (e.g. release of phenylalanine from L-Phe-Gly-Gly but not from Gly-Gly-L-Phe).

\begin{tabular}{|c|c|c|}
\hline Peptides & $\begin{array}{c}\text { Peptidase V } \\
\text { UK20(pKV102) }\end{array}$ & $\begin{array}{l}\text { Peptidase D } \\
\text { UK20(pJK13) }\end{array}$ \\
\hline$\beta$-Ala-L-Ala & + & + \\
\hline$\beta$-Ala- $\underline{\mathrm{L}-\mathrm{H} \text { is }}$ & + & + \\
\hline$\beta$-Ala-L-Ile & + & - \\
\hline$\beta$-Ala-L-Leu & + & + \\
\hline$\beta$-Ala-L-Met & + & + \\
\hline$\beta$-Ala-L-Phe & + & + \\
\hline$\beta$-Ala-L-Trp & + & + \\
\hline$\beta$-Ala-L-Tyr & + & + \\
\hline$\beta$-Ala-L-Val & + & - \\
\hline$\underline{L}-\mathrm{Ala}-\overline{\beta-\mathrm{Ala}}$ & - & - \\
\hline L-Ile- $\beta$-Ala & + & - \\
\hline L-Leu- $\beta$-Alà & + & - \\
\hline$\overline{\mathrm{L}-\mathrm{Met}}-\beta$-Ala & + & - \\
\hline L-Phe- $\beta$-Ala & + & - \\
\hline$\underline{\mathrm{L}}-\mathrm{Val}-\beta-\mathrm{Ala}$ & - & - \\
\hline D-Ala-L-Leu & + & + \\
\hline$\underline{\mathrm{L}-\mathrm{Ala}}-\underline{\mathrm{L}-\mathrm{Ala}}$ & + & + \\
\hline Gly-L-Phe & + & + \\
\hline L-Leu-Gly & + & - \\
\hline$\overline{\text { L-Leu-L-Leu }}$ & + & - \\
\hline L-Met-L-Met & + & + \\
\hline L-Phe-L-Phe & + & + \\
\hline$\overline{\mathrm{L}-\mathrm{Phe}-\mathrm{L}-\mathrm{Leu}}$ & + & - \\
\hline$\overline{\text { L-Pro-L-Leu }}$ & + & + \\
\hline$\underline{\mathrm{L}}-\mathrm{Ala}-\underline{\mathrm{L}}-\mathrm{Ala}-\underline{\mathrm{L}}-\mathrm{Ala}$ & - & - \\
\hline L-Ala-Gly-Gly & - & - \\
\hline L-Ala-L-Val-L-Leu & - & - \\
\hline L-Ala-L-Val-L-Leu & - & - \\
\hline Gly-Gly-L-His & - & - \\
\hline Gly-Gly-L-Phe & - & - \\
\hline Gly-Gly-L-Met & - & - \\
\hline Gly-L-Phe-L-Ala & - & - \\
\hline$\underline{\mathrm{L}}$-His-Gly-Gly & - & - \\
\hline$\overline{\mathrm{L}-\mathrm{H} \text { is }}-\mathrm{L}-$ Pro-L-Leu & - & - \\
\hline$\underline{\mathrm{L}-\mathrm{His}}-\mathrm{L}-$ Pro- $\mathrm{L}-\mathrm{Val}$ & - & - \\
\hline 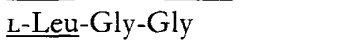 & - & - \\
\hline L-Leu-L-Leu-L-Leu & - & - \\
\hline$\underline{\text { L-Met-L-Ala-L-Ser }}$ & + & - \\
\hline$\overline{\mathrm{L}-\mathrm{Met}}-\mathrm{L}-\mathrm{Ala}-\mathrm{L}-\mathrm{Ser}$ & - & - \\
\hline L-Met-L-Met-L-Met & + & - \\
\hline L-Phe-Gly-Gly & + & - \\
\hline L-Phe-L-Phe-L-Phe & + & - \\
\hline Gly-Gly-Gly-L-Ala & - & - \\
\hline L-Phe-Gly-Gly-L-Phe & - & - \\
\hline$\underline{L}$-Phe-L-Phe-L-Phe-L-Phe & - & - \\
\hline
\end{tabular}




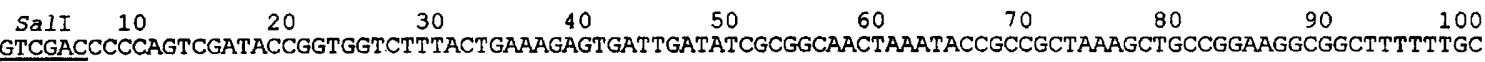

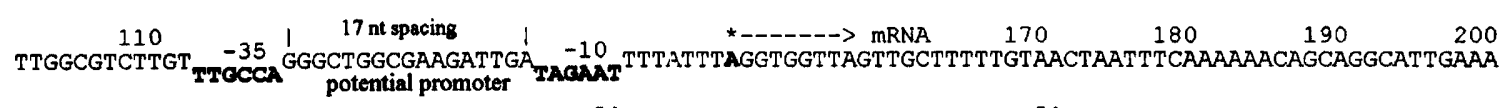
$210220 \quad 230 \quad 3^{\prime}$ GACCGCCTTCGGTTCTTCCTGCGCTAG ${ }^{5} 1280 \quad 290 \quad 300$ ATAAACATTAGGAGAAAAAGATGGACTTAAACTTTAAAGAACTGGCGGAAGCCAAGAAGGACGCGATCTTAAAAGACTTAGAGGAATTGATCGCCATTGA

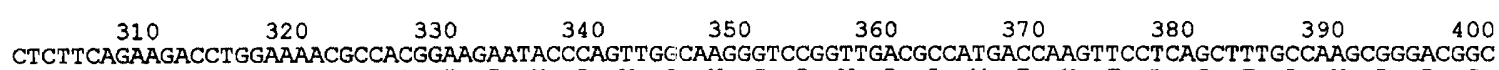

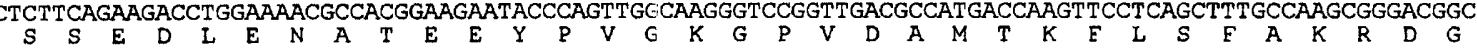
$\begin{array}{ccccccccc}410 & 420 & 430 & 440 & 450 & 460 & 470 & 480 & 490\end{array}$ TTTGACACGGAAAACTTCGCCAACTACGCCGGCCGGGTCAACTTCGGTGCAGGCGACAAGCGCCTGGGCATCATCGGCCACATGGACGTAGTGCCAGCTG
F $D$ T

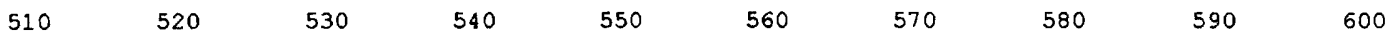
GTGAAGGCTGGACCCGGGACCCCTTCAAGATGGAAATCGACGAAGAAGGCCGGATCTACGGCCGGGGCAGCGCCGACGACAAGGGGCCAAGCTTAACTGC

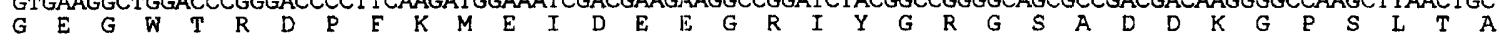

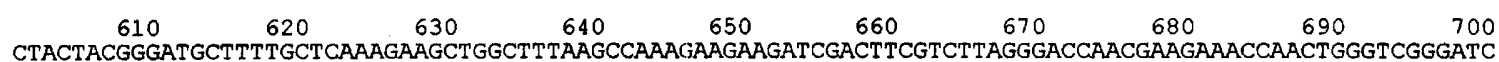

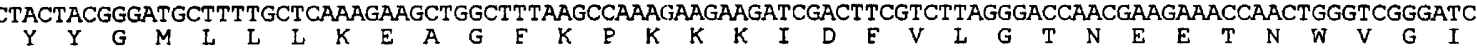

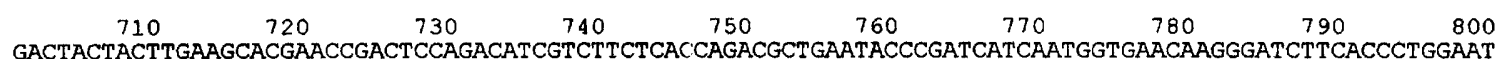
GACTACTACTTGAAGCACGAACCGACTCCAGACATCGTCTTCTCACCAGACGCTGAATACCCGATCATCAATGGTGAACAAGGGATCTTCACCCTGGAAT

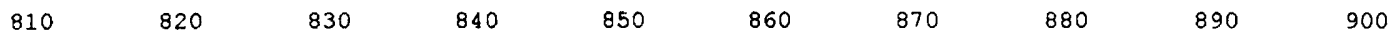
TCAGCTTCAAGAACGATGATACTAAGGGCGACTATGTTTTAGACAAGTTCAAGGCCGGGTTGCCACTAACGTGACTCCGCAGGTTACCCGGGCTACTAT

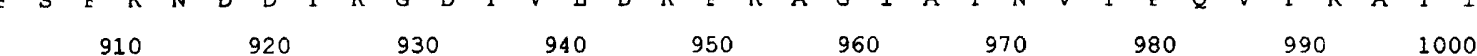

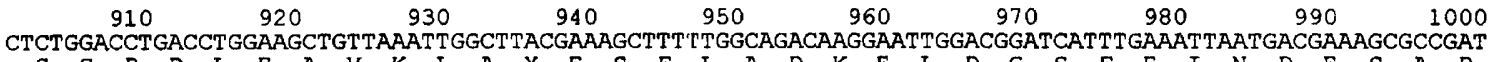

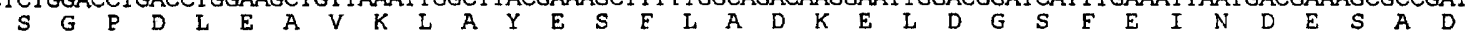

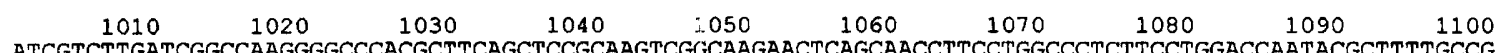

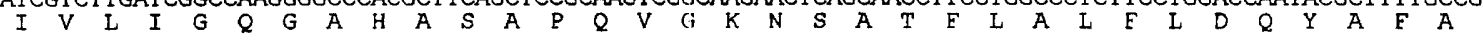

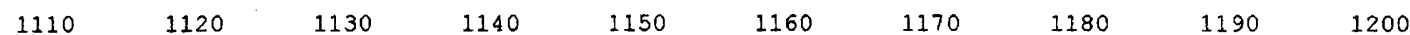
GCCGGGACAAGAACTTCCTCCACTTCCTGGCTGAAGTGGAACACGAA.GACTTCTATGGCAAGAAGCTGGGCATCTTCCACCACGATGATCTGATGGGCGA $\begin{array}{llllllllllllllllllllllllllllllllllll}G & R & D & K & N & F & L & H & F & L & A & E & V & E & H & E & D & F & Y & G & K & K & L & G & I & F & H & H & D & D & L & M & G & D\end{array}$

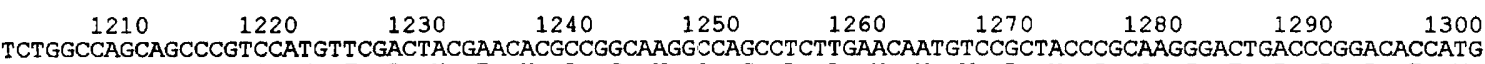

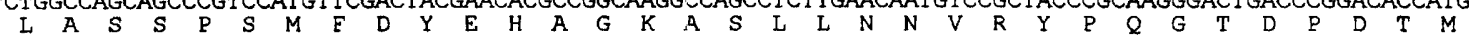

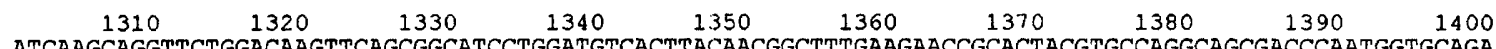
ATCAAGCAGGTTCTGGACAAGTTCAGCGGCATCCTGGATGTCACT TACAACGGCTTTGAAGAACCGCACTACGTGCCAGGCAGCGACCCAATGGTGCAGA

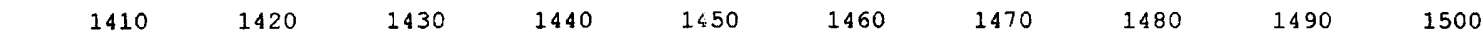
CTTTGCTCAAGGTTTACGAAAAACAAACCGGCAAGCCGGGCCACGAAGTCGTAATCGGCGGCGGGACTTACGGCCGCCTCTTTGAGCGCGGGGTTGCCTT $\begin{array}{lllllllllllllllllllllllllllllllllll}T & I & L & K & V & Y & E & K & Q & T & G & K & P & G & H & E & V & V & I & G & G & G & T & Y & G & R & L & E & E & R & G & V & A & F\end{array}$

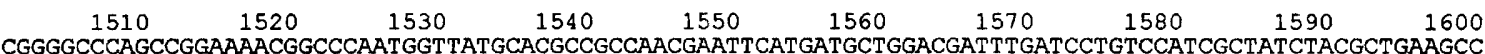

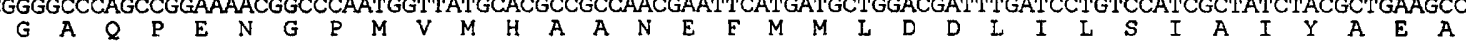

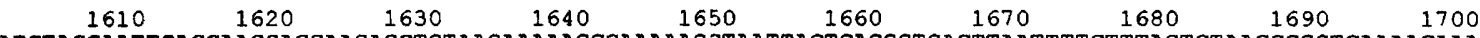
ATCTACGAATTGACCARGGACGAAGAGCTGTAAGAAAAAGCCAAAAAGGTAATTACTCAGGGT GACTTAATTTTCTTTAGTCTAACCCGGTCAAAACAAA

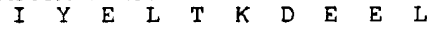

$\begin{array}{llllllllll}1710 & 1720 & 1730 & 1740 & 1750 & 1760 & 1770 & 1780 & -35 & 14 \text { nt spacing }\end{array}$ GCATTTTTAGCTTTAGCAGGTTGTCAAATTAATTTTATTTTGACAGCC'? GCTTTTTTTGCCCTTTCTTAAAGGATTTTATC TTTAGAA AAAAGACTGAAT

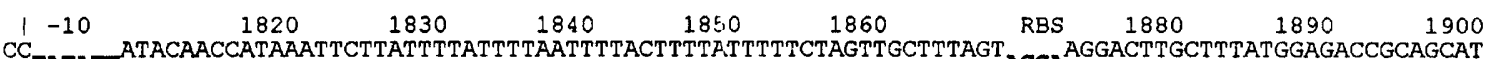
$\mathrm{CC}_{\text {TATATT }}$ ATACAACCATAAATTCTTATTTTATTTTAATTTACTTTTATTTTTCTAGTTGCTTTAGT AGGA AGGACTTGCTTTATGGAGACCGCAGCAT

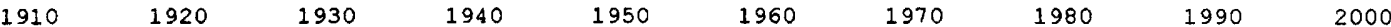
TGAAAACACGGACGGGACTATCCGCTCCTTGTCCAACCGGCACGTGCAGATGATTGCCATTGGCGGCACGATCGGTACTGGCCTCTTCTTGGGGGCCGGG $\begin{array}{llllllllllllllllllllllllllllllllll}E & N & T & D & G & T & I & R & S & L & S & N & R & H & V & Q & M & I & A & I & G & G & T & I & G & T & G & L & F & L & G & A & G\end{array}$

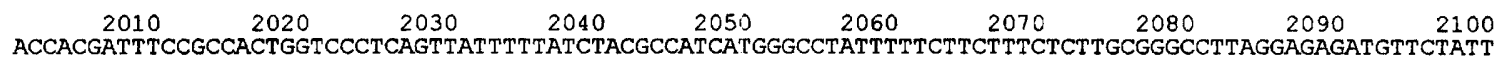
$\underset{T}{\text { ACCACGATTTCCGCCACTGGTCCCTCAGTTATTTTTATCTACGCCATCATGGGCCTATTTTTCTTCTTTCTCTTGCGGGCCTTAGGAGAGATGTTCTATT }}$

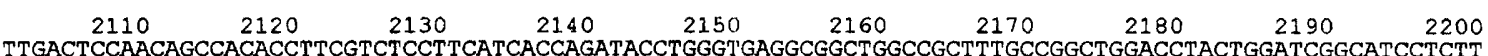

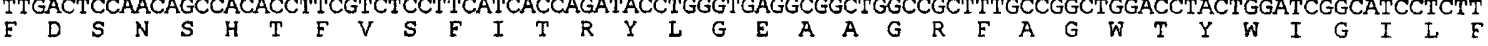

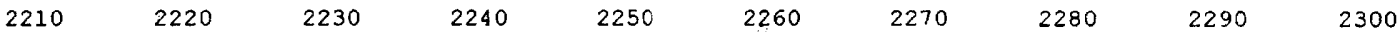
TGCCTGCATGGCGGAGCTGACGGCCGTTTCAACCTATGTACAGTACTGGCTGCCCGGCCTGCCCGCCTGGCTGATTGAAGTTAGCGTCCTAGGCCTCTTG

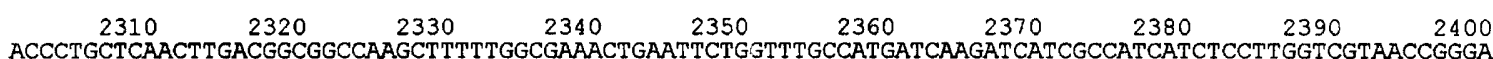

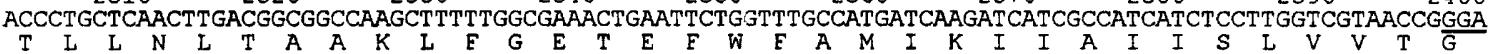

$\frac{\mathrm{TCC}}{\mathrm{I}}$

Fig. 4. For legend see facing page. 


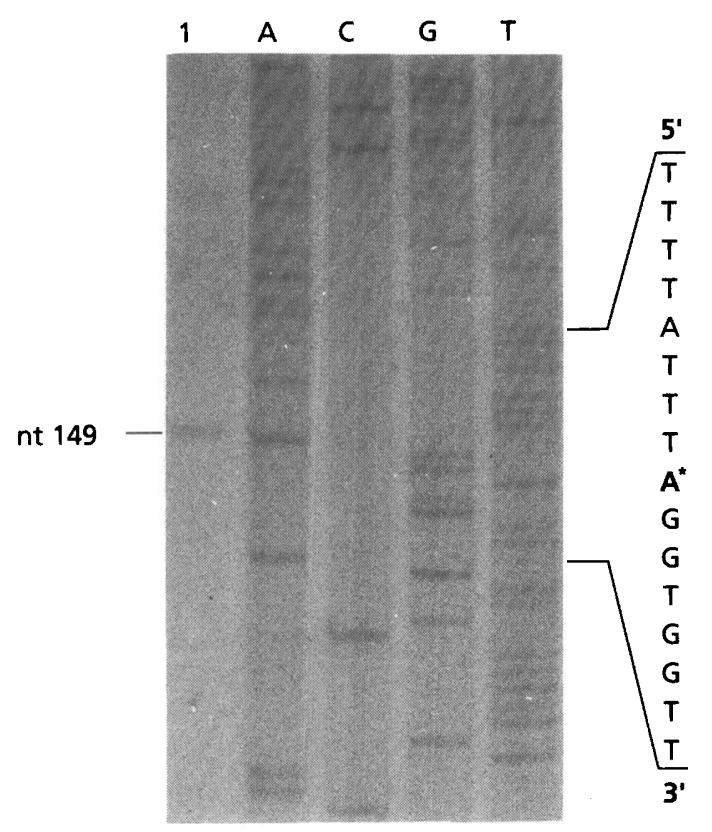

Fig. 5. Mapping of the $5^{\prime}$ end of the pep $V$ transcript by primer extension. The 27-mer oligonucleotide (Fig. 4) complementary to the sequence near the $5^{\prime}$ end of the pep $V$ coding region was used to prime cDNA synthesis of RNA from $L b$. delbrueckii subsp. lactis DSM 7290 (lane 1). Reference sequencing reactions (lanes $A, C, G$ and $T$ ) were performed with the same primer on double-stranded plasmid pKV104 as the template. The sequence of the antisense DNA strand in the region of transcription is shown to the right of the panel. The $3^{\prime}$ terminus of the extended product complementary to the $5^{\prime}$ end of the pepV RNA assigned to an A-residue is marked by an asterisk.

nucleotide 1630 , is sufficient to encode a protein of 470 amino acids with a calculated molecular mass of $51998 \mathrm{Da}$. This value agrees closely with the $52 \mathrm{kDa}$ molecular mass of peptidase $\mathrm{V}$ as estimated by SDS-PAGE. A potential ribosome-binding site (AGGAG) is present 7 bp upstream of the predicted ATG start codon, which is similar to those reported for E. coli (Shine \& Dalgarno, 1974) and Lactococcus lactis (van de Guchte, 1992).

The hydrophilicity plot of the deduced amino acid sequence according to Rao \& Argos (1986) did not show any obvious membrane-spanning domains (data not shown) and searching the $\mathrm{N}$-terminus did not reveal any putative signal peptide sequence. This suggests that PepV might be an intracellularly located enzyme. However, the cellular distribution of PepV in $L b$. delbrueckii subsp. lactis DSM 7290 needs to be further investigated. ORF2, located on the same DNA strand downstream of pepV, runs from the unusual T'TG start codon at position 1878 to the end of the cloned insert at position 2403. Since no translation stop codon could be detected, ORF2 does not encode a complete gene.

\section{Determination of the transcription initiation site}

To identify the precise location of the $5^{\prime}$ end of the pep $V$ mRNA, we performed primer extension analysis. A synthetic oligonucleotide primer of $27 \mathrm{nt}$ complementary to nucleotides 242--268 of the antisense strand (Fig. 4) was hybridized to mRNA isolated from $L b$. delbrueckii subsp. lactis DSM 7290. The extended cDNA indicated that the start point of pep $V$ transcription is the $A$ residue at position 149 (Fig. 5). Analysis of the nucleotide sequence in the close range upstream of the +1 region revealed a putative promoter area with considerable homology to the E. coli consensus promoter (Harley \& Reynolds, 1987). The two detected conserved sequences TTGcCA and TAgAAT closely resemble the -35 and -10 boxes of the E. coli consensus promoter, respectively. Moreover the two boxes are separated by $17 \mathrm{bp}$, which complies with the canonical spacing in E. coli. Taken together, the similarity of the Lactobacillus transcription and translation signals to those observed in $E$. coli is consistent with the observation that heterologous expression of $p e p V$ was very efficient in E. coli. As in the case of this Lactobacillus gene, considerable homologies were found between the expression signals of $L c$. lactis and E. coli (van de Guchte et al., 1992).

\section{Homologies of the Lb. delbrueckii subsp. lactis sequence}

When searching the EMBL database with the pepV nucleotide or amino acid sequence, no significant homology to any sequences could be detected. No similarities were found with any peptidase or protease sequenced previously. Although complementation of E. coli pepD by the Lactobacillus pep $V$ gene was used for screening, the sequences of the two genes are distinct. Comparison with an unpublished dipeptidase from Lc. lactis NCDO 712 (P. Strøman, personal communication) revealed considerable homology ( $47 \%$ identity over their entire length of 470 amino acids). Because of this striking homology, indicating a close phylogenetic relation between the

Fig. 4. Nucleotide sequence of the chromosomal insert of plasmid pKV104. The coding region for pepV (nt 221-1630) and the partial ORF for the predicted amino acid permease (nt 1878-2403) are translated into the amino acid sequence given below the nucleotide sequence. Seven nucleotides upstream of the pepV ATG start codon, and six nucleotides upstream of the ORF2 TTG start codon, well-conserved ribosome-binding sites (RBS) are present. Primer extension, using a 27-mer oligonucleotide complementary to mRNA (nt 242-268), identified nt 149 as the transcriptional start (A-residue shown above the nucleotide sequence of pepV. Searching the upstream region of the mRNA-starting point revealed the potential promoter region indicated. The potential ORF2 promoter is predicted by sequence analysis. The underlined region of dyad symmetry displaying typical features of a rho-independent transcription terminator is centred around nucleotide 1733 (Brendel \& Trifonov, 1984). It is capable of forming a $G+C$-rich stem-loop structure with a $\Delta G$ value of $-14.6 \mathrm{kcal} \mathrm{mol}^{-1}\left(61.1 \mathrm{~kJ} \mathrm{~mol}^{-1}\right)$, and is followed by a stretch of 6 T-residues. The two flanking restriction sites used for subcloning are indicated. 


\begin{tabular}{|c|c|c|c|c|c|}
\hline Lb_PepV & MDLNF & KELAEAKKDAIL & KDLEELI & AID & SSEDL \\
\hline EC_DapE & MS & CPVIE & QQL IRRP & SLS & PDD \\
\hline c_ArgE & MKNKL & PPFIE & RALIATP & SIS & ATE \\
\hline 8_CpG2 & MRPS I HRTA IAAVLATAF & STALAQKRDNVLFS & DEQPAVIK & TLEK & VNIETG \\
\hline
\end{tabular}

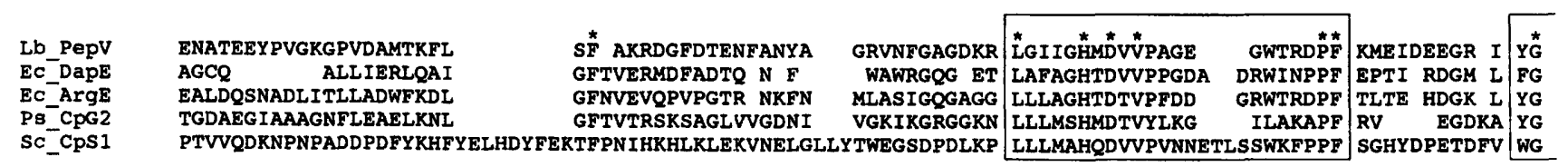

Lo_PepV
Ec_DapE
Ec_ArgE
Ps_CpG2
Sc_CpS1

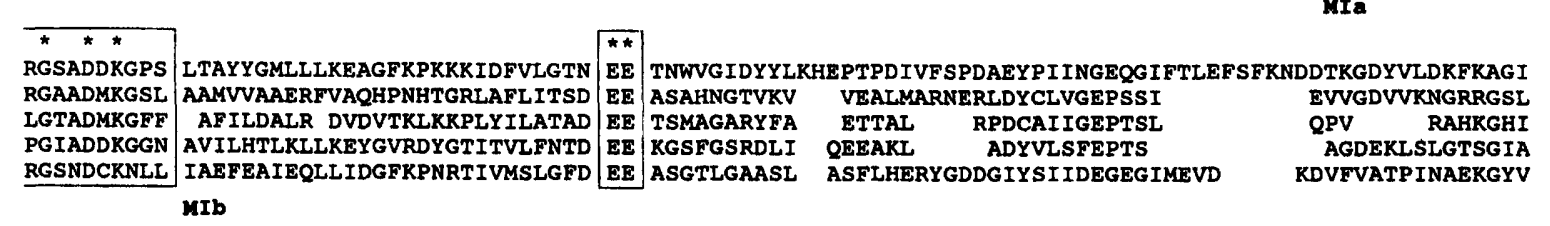

ATNVTPQVTRATIS GPDLEAVKLAYE SFLADKELDGSFEINDESADIVIIGQGAHASAPQVGKN

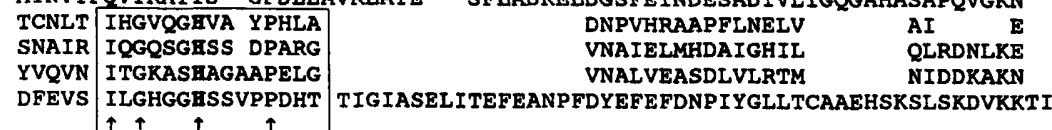

SATFLALFLDQYAFA GRDKN

TIGIASELITEFEANPFDYEFEFDNPIYGLLTCAAEHSKSLSKDVKKTILGAPFCPRRKDRLVEY ISNOSHLRTLIRTTQ

MII

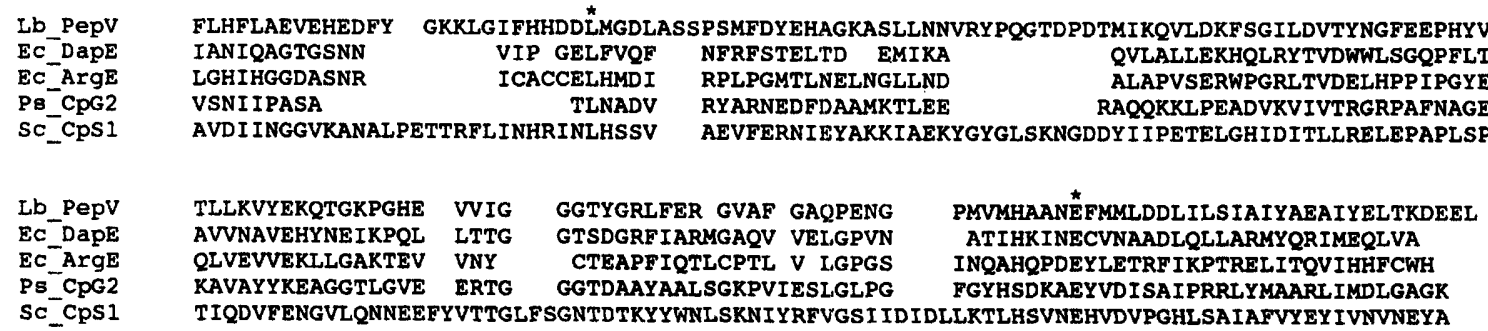

Fig. 6. Progressive alignment of the PepV protein sequence with proteins of the ArgE/DapE/CPG2/YscS family, using the program TREE (Feng \& Doolittle, 1987). The PepV sequence displays only weak homology over its entire length (ArgE $20 \%$; DapE 17.8\%; CPG2 18.7\%; CPS1 17.9\%) but the consensus regions Mla and Mlb are well conserved. Strictly conserved amino acids in all five sequences are marked by an asterisk. The ArgE/DapE/CPG2/YscS family signatures are boxed and labelled Mla, MIb and MII. The PROSITE pattern MIb was recently replaced by Mla, containing one of the two histidine residues demanded for binding of the metal ions. Consensus pattern Mla (last update October 1993): [FY]-G-XG-x-A-D-x-K-G-x(2)-A. Consensus pattern MIb: [LIVMF]-x-[GSA]-H-x-D-x-V-x(9,13)-P-F. Consensus pattern MII: I-x-G-x(2)[SAG]-H-x-[SAG]-x(1,2)-P-x(2)-[SAGT]; the strictly conserved amino acids in this pattern are labelled by an arrow.

respective peptidases from $L b$. delbrueckii subsp. lactis DSM 7290 and Lc. lactis NCDO 712, both these genes have been designated $p e p V$.

We searched PepV with BLIMPS (BLOCKS IMPROVED Searcher), a searching tool that scores a protein sequence against the BLOCKS database. This program is capable of detecting and evaluating distant relationships (Henikoff \& Henikoff, 1991; Wallace \& Henikoff, 1992). We further searched PepV with prosite, a similar program, using pattern matching and thus allowing detection of domains with biological functions, active sites of enzymes and sequence 'signatures' specific to a family or group of proteins (Bairoch, 1992, 1993).

Both analyses revealed homology to the signature sequence of the ArgE/DapE/CPG2/YscS family of proteins (Boyen et al., 1992; Meinnel et al., 1992; Spormann et al., 1991). The enzymes of this family, acetylornithine deacetylase (coded by gene argE from $E$. coli), succinyldiaminopimelate desuccinylase (dapE from $E$. coli), car- boxypeptidase G2 (cpg2 from Pseudomonas), vacuolar carboxypeptidase $\mathrm{S}$ (yscS from yeast), have been shown to be evolutionarily and functionally related. They share the common characteristics of hydrolysis of amide bonds in substrates with similar structure, dependence on cobalt or zinc for activity, and a size of 40 to $60 \mathrm{kDa}$, and they also show a number of regions of sequence similarity. Two conserved regions were selected as PROSITE signature patterns, one located in the $\mathrm{N}$-terminal section of the enzymes and the second located in the central part. Each pattern contains one of the two conserved histidine residues in these enzymes, which are thought to be involved in the binding of the metal ions.

Peptidase V from Lactobacillus appeared to contain only the first motif, and not the second histidine-containing pattern (Fig. 6). The same was observed for the lactococcal enzyme (P. Strøman, personal communication; data not shown). PepV, being a metallohydrolase, might have a different histidine residue involved in catalysis. The 
Table 3. Amino acid (aa) homologies of the putative amino acid permease from $L b$. delbrueckii subsp. lactis DSM 7290 (BlastX-Analysis*)

\begin{tabular}{|c|c|c|c|}
\hline Enzyme & Organism & $\begin{array}{c}\text { Percentage } \\
\text { identity } \\
\text { (aa residues) }\end{array}$ & $\begin{array}{c}\text { Percentage } \\
\text { similarity } \\
\text { (aa residues) }\end{array}$ \\
\hline Aromatic amino acid transport protein (aroP), 456 aa & E. coli & $45(72 / 159)$ & $73(112 / 159)$ \\
\hline Phenylalanine specific permease $(p h e P), 458$ aa & E. coli & $45(71 / 156)$ & $69(109 / 156)$ \\
\hline$\gamma$-Aminobutyric acid permease $(g a b P), 466$ aa & E. coli & $34(53 / 155)$ & $60(94 / 155)$ \\
\hline Lysine specific permease $($ lys $P), 489$ aa & E. coli & $29(40 / 137)$ & $56(77 / 137)$ \\
\hline Proline specific permease 570 aa & S. cerevisiae & $37(33 / 89)$ & $61(55 / 89)$ \\
\hline Arginine permease, 590 aa & S. cerevisiae & $32(38 / 118)$ & $55(65 / 118)$ \\
\hline General amino acid permease, 601 aa & S. cerevisiae & $37(40 / 107)$ & $63(63 / 107)$ \\
\hline Histidine permease, 532 aa & $\begin{array}{l}\text { Saccbaromyces } \\
\text { cerevisiae }\end{array}$ & $45(17 / 37)$ & $81(30 / 37)$ \\
\hline Proline specific permease, 570 aa & $\begin{array}{l}\text { Aspergillus } \\
\text { nidulans }\end{array}$ & $53(23 / 43)$ & $86(37 / 43)$ \\
\hline
\end{tabular}

* Altschul et al. (1990).

alignment revealed conservation of two adjacent glutamic acid residues (Fig. 6), which are likely to participate in chelating of the presumed metal ion as found in a number of $\mathrm{Zn}$-metalloproteases.

This finding might indicate a new family of peptidases with homology to the ArgE/DapE/CPG2/YscS proteins but, due to the lack of the second consensus pattern, having a different catalytic site. The inhibition of PepV by metal ion chelating agents confirms our classification as a metalloenzyme, but the physiological activity of PepV, as an exclusively peptide-degrading enzyme, is not certain. The cleavage of unusual $\beta$-alanyl peptides and the homology to the ArgE/DapE/CPG2/YscS family might suggest participation in metabolic pathways having nothing in common with casein degradation.

The putative ORF2 protein showed significant homologies to the $\mathrm{N}$-termini of a variety of amino acid permeases from different species (Table 3). The size of the most homologous permeases from E. coli ranges from 456 to 489 amino acids, so we calculated that approximately $40 \%$ of the presumed Lactobacillus gene is present on the cloned fragment. Since permeases are involved in the overall process of casein utilization, detailed knowledge of the transport systems specific for the products of degradation is needed. We are therefore currently screening the plasmid library for the missing part of the gene using colony blot hybridization with a labelled DNA probe.

\section{ACKNOWLEDGEMENTS}

This work was supported by the BRIDGE T-Project 'Biotechnology of Lactic Acid Bacteria' of the EC and by the Bundesministerium für Forschung und Technologie grant 0319281B. The authors are responsible for the content of this publication. We acknowledge the excellent technical assistance of Bernd Winkelmann.

\section{REFERENCES}

Abo-Elnaga, I. G. \& Plapp, R. (1987). Peptidases of Lactobacillus casei and Lactobacillus plantarum. J Basic Microbiol 27, 123-130.

Altschul, S. F., Gish, W., Miller, W., Myers, E. W. \& Lipman, D. J. (1990). Basic local alignment search tool. J Mol Biol 215, 403-410.

Ames, F. \& Adeshir, F. L. (1980). Cloning of the histidine transport genes from Salmonella typhimurium and characterization of an analogous transport system in Escherichia coli. J Supramol Struct 13, 117-130.

Atlan, D., Gilbert, C., Blanc, B. \& Portalier, R. (1994). Cloning, sequencing and characterization of the pepIP gene encoding a proline iminopeptidase from Lactobacillus delbrueckii subsp. bulgaricus CNRZ 397. Microbiology 140, 527-535.

Bairoch, A. (1992). PRosite: a dictionary of sites and patterns in proteins. Nucleic Acids Res 20, 2013-2018.

Bairoch, A. (1993). The PROSITE dictionary of sites and patterns in proteins, its current status. Nucleic Acids Res 21, 3097-3103.

Birnboim, H. C. \& Doly, J. (1979). A rapid alkaline extraction procedure for screening recombinant plasmid DNA. Nucleic Acids Res 7, 1513-1523.

Boyen, A., Charlier, D., Charlier, J., Sakanyan, V., Mett, I. \& Glansdorff, N. (1992). Acetylornithine deacetylase, succinyldiaminopimelate desuccinylase and carboxypeptidase G2 are evolutionarily related. Gene 116, 1-6.

Brendel, V. \& Trifonov, E. N. (1984). A computer algorithm for testing prokaryotic terminators. Nucleic Acids Res 12, 4411-4427.

Davis, B. B. \& Mingioly, E. S. (1950). Mutants of Escherichia coli requiring methionine or vitamin B12. J Bacteriol 60, 17-28.

Davis, B. J. (1964). Disc electrophoresis II. Ann NY Acad Sci 121, 404427.

De Man, J. C., Rogosa, M. \& Sharpe, M. E. (1960). A medium for the cultivation of Lactobacilli. J Appl Bacteriol 23, 130-135.

Dower, W. J., Miller, J. F. \& Ragsdale, C. W. (1988). High efficiency transformation of $E$. coli by high voltage electroporation. Nucleic Acids Res 16, 2127-2145.

Feng, D. F. \& Doolittle, R. F. (1987). Progressive sequence alignment as a prerequisite to correct phylogenetic trees. $J$ Mol Evol $25,351-360$. 
van de Guchte, M., Kok, J. \& Venema, G. (1992). Gene expression in Lactococcus lactis. FEMS Microbiol Rev 88, 72-92.

Harley, C. B. \& Reynolds, R. P. (1987). Analysis of E. coli promoter sequences. Nucleic Acids Res 15, 2343-2361.

Henikoff, S. \& Henikoff, J. G. (1991). Automated assembly of protein blocks for database searching. Nucleic Acids Res 19, 6565-6572.

Henrich, B., Monnerjahn, U. \& Plapp, R. (1990). Peptidase D gene $(p e p D)$ of Eschericbia coli K-12: nucleotide sequence, transcript mapping, and comparison with other peptidase genes. $J$ Bacteriol 172, 4641-4651.

Henrich, B., Becker, S., Schroeder, U. \& Plapp, R. (1993). DCP gene of Escherichia coli: cloning, sequencing transcript mapping and characterization of the gene product. J Bacteriol 175, 7290-7300.

Holck, A. \& Naes, H. (1992). Cloning, sequencing and expression of the gene encoding the cell-envelope-associated proteinase from Lactobacillus paracasei subsp. paracasei NCDO151. J Gen Microbiol 138, 1353-1364.

Ikemura, T. \& Dahlberg, J. E. (1973). Small ribonucleic acids of Escherichia coli. Characterization by polyacrylamide gel electrophoresis and finger print analysis. J Biol Chem 248, 5024-5032.

Kirsh, M., Dembinsky, D. R., Hartman, P. E. \& Miller, C. G. (1978). Salmonella typhimurium peptidase active on carnosine. J Bacteriol 134, 361-374.

Klein, J. R., Henrich, B. \& Plapp, R. (1986). Cloning and expression of the pepD gene of Escherichia coli.J Gen Microbiol 132, 2337-2343.

Klein, J. R., Klein, U., Scad, M. \& Plapp, R. (1993). Cloning, DNA sequence analysis and partial characterization of $p e p N$, a lysyl aminopeptidase from Lactobacillus delbrueckii subsp. lactis DSM7290. Eur J Biochem 217, 105-114.

Klein, J. R., Schmidt, U. \& Plapp, R. (1994). Cloning, heterologous expression, and sequencing of the proline iminopeptidase gene, pepI, from Lactobacillus delbrueckii subsp. lactis DSM 7290. Microbiology 140, 1133-1139.

Kunze, N., Kleinhauf, H. \& Bauer, K. (1986). Characterization of two carnosinase-degrading enzymes from rat brain. Partial purification and characterization of a carnosinase and a $\beta$-alanyl-arginine hydrolase. Eur J Biochem 160, 605-613.

Laemmli, U. K. (1970). Cleavage of structural proteins during the assembly of the head of bacteriophage T4. Nature 227, 680-685.

Law, B. A. \& Kolstadt, J. (1983). Proteolytic systems in lactic acid bacteria. Antonie Leeuvenboek 49, 225-245.

Meinnel, T., Schmitt, E., Mechulam, Y. \& Blanquet, S. (1992). Structural and biochemical characterization of the Escherichia coli argE gene product. J Bacteriol 174, 2323-2331.

Meyer-Barton, E. C., Klein, J. R., Iman, M. \& Plapp, R. (1993). Cloning and sequence analysis of the X-prolyl-dipeptidyl-aminopeptidase gene ( $p e p X)$ from Lactobacillus delbrueckii subsp. lactis DSM7290. Appl Microbiol Biotechnol 40, 82-89.

Miller, C. G. \& Schwartz, G. (1978). Peptidase deficient mutants of Escherichia coli. J Bacteriol 135, 603-611.

Nowakowski, C. M., Bhowmik, T. K. \& Steele, J. L. (1993). Cloning of peptidase genes from Lactobacillus belveticus CNRZ 32. Appl Microbiol Biotecbnol 39, 204-210.

Raleigh, E. A., Murray, N. E., Revel, H., Blumenthal, R. M., Westawy, D., Reith, A. D., Rigby, P. W. J., Elhai, J. \& Hanahan, D. (1988). McrA and McrB restriction phenotypes of some E. coli strains and implication for gene cloning. Nucleic Acids Res 16, 1563-1575.

Rao, M. J. K. \& Argos, P. (1986). A conformational preference parameter to predict helices in integral membrane proteins. Biochim Biopbys Acta 869, 197-214.

Sambrook, J., Fritsch, E. F. \& Maniatis, T. (1989). Molecular Cloning: a Laboratory Manual, 2nd edn. Cold Spring Harbor, NY: Cold Spring Harbor Laboratory.

Sanger, F., Nicklen, S. \& Coulson, A. R. (1977). DNA sequencing with chain terminating inhibitors. Proc Natl Acad Sci USA 74, 5463-5467.

Shine, J. \& Dalgarno, L. (1974). The 3'-terminal sequence of Escherichia coli $16 \mathrm{~S}$ ribosomal RNA: complementarity to nonsense triplets and ribosome binding sites. Proc Natl Acad Sci USA 71, 1342-1346.

Spormann, D. O., Heim, J. \& Wolf, B. H. (1991). Carboxypeptidase yscS: gene structure and function of the vacuolar enzyme. Eur $J$ Biocbem 197, 399-405.

Stoker, N. G., Fairweather, N. F. \& Spratt, B. G. (1982). Versatile low copy number plasmid vectors for cloning in Eschericbia coli. Gene 18, 335-341.

Sugiura, M., Ito, Y., Hirano, K. \& Sawaki, S. (1977). Detection of dipeptidase and tripeptidase activities on poly acrylamide gel and cellulose acetate gel by reduction of tetrazolium salts. Anal Biochem 81, 481-484.

Sutcliffe, J. G. (1979). Complete nucleotide sequence of the E. coli plasmid pBR322. Cold Spring Harbor Symp Quant Biol 43, 77-90.

Thomas, T. D. \& Pritchard, D. D. (1987). Proteolytic enzymes of dairy starter cultures. FEMS Microbiol Rev 46, 245-268.

Wallace, J. C. \& Henikoff, S. (1992). ратмAт: a searching and extraction program for sequence, pattern and block queries and databases. Computer Appl Biosci 8, 249-254.

Wang, R. F. \& Kushner, S. R. (1991). Construction of versatile lowcopy-number vectors for cloning, sequencing and gene expression in Eschericbia coli. Gene 100, 195-199.

Weber, K. \& Osborn, M. (1969). The reliability of molecular weight determinations by dodecyl sulfate-polyacrylamide gel electrophoresis. J Biol Chem 244, 4406-4412.

Williamson, D. H. (1985). L-Alanine: determination with alanine dehydrogenase. In Methods of Enzymatic Analysis, vol. 8, pp. 341-344. Edited by H. U. Bergmeyer. Weinheim, Federal Republic of Germany: VCH Publishers.

Yanisch-Peron, C., Vieira, J. \& Messing, J. (1985). Improved M13 phage cloning vectors and host strains: nucleotide sequence of M13mp18 and pUC19 vectors. Gene 33, 103-119.

Received 21 March 1994; revised 2 June 1994; accepted 9 June 1994. 